\title{
HUBUNGAN PEMBERIAN SUSU FORMULA DENGAN KEJADIAN DIARE PADA BAYI USIA 1-6 BULAN DI DESA TAMBAK CEKUR KECAMATAN SERBAJADI KABUPATEN SERDANG BEDAGAI TAHUN 2019
}

\author{
Kardina Hayati ${ }^{1}$, Grace Elizabeth Simanullang ${ }^{2}$ \\ Institut Kesehatan MEDISTRA Lubuk Pakam \\ Jl. Sudirman No 38 Lubuk Pakam Kab.Deli Serdang, Sumatera Utara. \\ e-mail: kardinahayati@medistra.ac.id
}

DOI: https://doi.org/10.35451/jkf.v1i2.153

\begin{abstract}
Formula milk was a type of prelactal food that was often given to neonates before breast milk comes out. Giving formula milk that was not good can increase the risk of diarrhea in infants because the brewing process was too thick and the way to store formula milk was wrong. The purpose of this study was to find out the relationship between the way of serving formula milk with diarrhea events in Tambak Cekur Village, Serbajadi District, Serdang Bedagai Regency in 2019. The type of research conducted in this study was nonexperimental, namely collecting data or observations simultaneously between independent variables and dependent variables. by using the Total Sampling method with a sample of 20 respondents Data collection using a questionnaire given to respondents and using Chi Square test data analysis. The results obtained were $p$ value $(0.001)<(0.05)$ or $p$ value $=0.34$ which means there was a relationship between the way of serving formula milk with the incidence of diarrhea in infants aged 0-6 months in Tambur Tambur, Serbajadi District, Serdang Bedagai Regency, Year 2019. Infants given formula milk did not provide protection, while diarrhea occurs from infants who were given formula milk. It was hoped that medical staff working at the puskesmas will know how to prepared formula milk to babies to avoid diarrhea.
\end{abstract}

Keywords: Formula milk, Diarrhe, Infants

\section{Pendahuluan}

Penyakit Diare menjadi masalah kesehatan di dunia termasuk Indonesia. Menurut WHO dan UNICEF, terdapat sekitar 2 miliyar kasus penyakit diare di seluruh dunia setiap tahun (Kemenkes, 2013).

Penyebab utama kematian karena diare adalah dehidrasi. Angka kejadian diare lebih sedikit jika bayi diberi ASI Eksklusif ini terjadi karena kandungan antibodi yang tidak dimiliki oleh susu formula dan nilai gizi ASI yang tinggi (Hardi, 2012) Susu buatan pabrik seperti susu formulasi telah di formulasi menyerupai ASI, walau ASI tetap yang terbaik (Sutomo dkk, 2011).

Pertumbuhan bayi dapat tertanggu jika takaran yang diberikan tidak tepat, obesitas salah 
satu akibat dari pemberian yg berlebihan. Sedangkan marasmus atau kurang gizi terjadi jika pemberian susu formula terlalu encer atau jumlahnya dibatasi. Diare salah satu akibat dari penggunaan susu formula bayi yang tidak benar atau tidak tepat sehingga dapat menimbulkan bahaya kesehatan. Pertumbuhan bakteri sangat udah berkembang dalam media susu, jika pemberian susu formula kurang memperhatikan segi antiseptik maka kita akan mudah terkontaminasi bakteri (Khasanah, 2011) .

Gangguan saluran pencernaan (muntah, diare) (Khasanah, 2011), meningkatkan kejadian karies gigi susu (Nasir, 2011), menurunkan perkembangan kecerdasan kognitif (Nasir, 2011), meningkatkan resiko kegemukan (obesitas) (Khasanah, 2011), meningkatkan resiko penyakit jantung dan pembuluh darah (Nasir, 2011), meningkatkan resiko infeksi yang berasal dari susu formula yang tercemar (Weir (2002) dalam Roesli, 2010), meningkatkan kurang gizi (Roesli, 2010), meningkatkan resiko kematian (Praptiani, 2012) merupakan efek dari pemberian susu formula.

Berdasarkan data awal di desa tambak cekur selama 3 bulan terakhir pada bulan agustusnovember 2018 terdapat sebanyak 20 balita yang menderita diare yang berusia 6 bulan -12 bulan.

Berdasarkan latar belakang di atas maka peneliti tertarik untuk melakukan penelitian dengan judul
Hubungan Cara Penyajian Susu Formula Dengan Kejadian Diare di Desa Tambak Cekur Kecamatan Serbajadi Kabupaten Serdang Bedagai Tahun 2019.

\section{METODE}

Jenis penelitian yang dilakukan dalam penelitan ini adalah non ekperimental yaitu Deskriptf Korelatif. Lokasi penelitian dilaksanakan di Desa Tambak Cekur Kecamatan Serba Jadi Kabupaten Serdang Bedagai. Waktu Penelitan ini dilakukan mulai September 2018 - Februari 2019. Populasi penelitian ini adalah seluruh anak balita yang berusia 6 bulan -12 bulan yang terkena diare. Teknik pengambilan sampel dalam penelitian ini adalah Total Sampling dimana jumlah sampel sama dengan jumlah populasi yaitu sebanyak 20 orang. Alat pengumpulan data menggunakan kuisioner dengan tehnik wawancara. Analisa data dilakukan secara bertahap, analisa data univariat dengan tabel distribusi frekuensi dan analisa data multivariat menguji hipotesa dilakukan analisa statistik dengan menggunakan uji kategorik Chi Square Test pada tingkat kemaknaannya adalah $95 \%$ $(P=0,05)$.

\section{HASIL}

Tabel 1 Karakteristik Responden Hubungan Cara Penyajian Susu Formula Dengan Kejadian Diare Pada Anak 6 Bulan - 12 Bulan Di Desa Tambak Cekur Kecamatan Serba Jadi Kabupaten Serdang Bedagai 
Jurnal Keperawatan dan Fisioterapi (JKF), e-ISSN: 2655-0830

Vol. 1 No.2 Edisi November 2018-April 2019

https://ejournal.medistra.ac.id/index.php.JFK

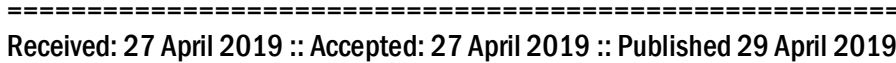

\begin{tabular}{lcc}
\hline Karakteristik & $\mathrm{f}$ & $(\%)$ \\
\hline Umur & & \\
a. 17-28 Tahun & 11 & 55 \\
b. 29-38 Tahun & 6 & 30 \\
c. >38 Tahun & 3 & 15 \\
Pendidikan & & \\
a. SD & 2 & 10 \\
b. SMP & 6 & 30 \\
c. SMA & 9 & 45 \\
d. Sarjana & 3 & 15 \\
Pekerjaan & & \\
a. PNS & 3 & 15 \\
b. Karyawan & 5 & 25 \\
c. IRT & 12 & 60 \\
\hline
\end{tabular}

Berdasarkan Tabel 1 diatas dapat dilihat bahwa distribusi karateristik responden berdasarkan umur diperoleh frekuensi terbanyak adalah responden dengan umur 1728 tahun sebanyak 11 orang (55\%). Berdasarkan pendidikan diperoleh hasil frekuensi terbanyak adalah responden dengan pendidikan SMA sebanyak 9 orang $(45 \%)$, sedangkan berdasarkan pekerjaan hasil frekuensi terbanyak adalah responden dengan pekerjaan IRT sebanyak 12 orang (60\%).

Tabel 2 Distribusi Responden Menurut Penyajian Susu Formula

\begin{tabular}{lll}
\hline $\begin{array}{l}\text { Cara Penyajian } \\
\text { Susu Formula }\end{array}$ & $\mathrm{f}$ & $\%$ \\
\hline $\begin{array}{l}\text { Tepat } \\
\text { Penyajian }\end{array}$ & 17 & 85 \\
$\begin{array}{l}\text { Tidak Tepat } \\
\text { Penyajian }\end{array}$ & 3 & 15 \\
\end{tabular}

Berdasarkan Tabel 2 di atas dapat dilihat bahwa distribusi responden berdasarkan cara penyajian susu formula dengan frekuensi terbanyak

\begin{tabular}{lcc}
\hline Kejadian Diare & $\mathrm{f}$ & $\%$ \\
\hline Terjadi & 9 & 45 \\
Tidak Terjadi & 11 & 55 \\
\hline
\end{tabular}

pada kategori tepat penyajian sebanyak 17 orang (85\%).

Tabel 3 Distribusi Responden Menurut Kejadian Diare

Berdasarkan Tabel 3 diatas dapat dilihat bahwa distribusi responden berdasarkan kejadian diare dengan frekuensi terbanyak pada kategori terjadi diare sebanyak 9 orang (45\%).

Tabel 4 Hubungan Cara Penyajian Susu Formula Dengan Kejadian Diare di Desa Tambak Cekur Kecamatan Serbajadi Kabupaten Serdang Bedagai Tahun 2019

\begin{tabular}{ccccccccc}
\hline & \multicolumn{4}{c}{ Diare } & & & \\
\cline { 2 - 5 } $\begin{array}{c}\text { Susu } \\
\text { Formula }\end{array}$ & \multicolumn{4}{c}{$\begin{array}{c}\text { Tidak } \\
\text { Terjadi }\end{array}$} & \multicolumn{2}{c}{ Terjadi } & & $\begin{array}{c}p- \\
\text { value }\end{array}$ \\
\cline { 2 - 5 } & $\mathrm{n}$ & $\%$ & $\mathrm{n}$ & $\%$ & & & \\
\hline Tepat & 3 & 33 & 11 & 100 & 17 & 85 & 0,03 \\
Tidak & & & & & & & \\
Tepat & 6 & 67 & 0 & 0 & 3 & 15 & 4 \\
\hline Jumlah & 9 & 100 & 11 & 100 & 20 & 100 & \\
\hline
\end{tabular}

\section{Berdasarkan Tabel 4 diatas} dapat dilihat bahwa distribusi responden menunjukkan bahwa bayi yang diberikan tepat penyajian susu formula lebih rendah terjadi diare $(33 \%)$ dibandingkan dengan tidak tepat penyajian susu formula terjadi diare (67\%). Sedangkan tepat penyajian susu formula lebih tinggi tidak terjadi diare (100\%) dibandingkan dengan tidak tepat penyajian susu formula tidak terjadi diare $(0 \%)$. Hasil perhitungan 
statistic menggunakan diperoleh nilai $\mathrm{p}=0,034(p$-value $<0,05)$.

\section{PEMBAHASAN}

Berdasarkan Tabel 1 di atas dapat dilihat bahwa distribusi karateristik responden berdasarkan umur diperoleh frekuensi terbanyak adalah responden dengan umur 1728 tahun sebanyak 11 orang (55\%). Berdasarkan pendidikan diperoleh hasil frekuensi terbanyak adalah responden dengan pendidikan SMA sebanyak 9 orang $(45 \%)$, sedangkan berdasarkan pekerjaan hasil frekuensi terbanyak adalah responden dengan pekerjaan IRT sebanyak 12 orang $(60 \%)$. Karakteristik responden sebagian besar adalah tamat SMA dimana responden seharusnya memiliki pengetahuan yang cukup untuk memilih jenis susu formula yang tepat.

Berdasarkan Tabel 2 diatas dapat dilihat bahwa distribusi responden berdasarkan cara penyajian susu formula dengan frekuensi terbanyak pada kategori tepat penyajian sebanyak 17 orang (85\%), dan berdasarkan Tabel 3 diatas dapat dilihat bahwa distribusi responden berdasarkan kejadian diare dengan frekuensi terbanyak pada kategori terjadi diare sebanyak 9 orang (45\%).

Bayi yang diberikan susu formula mempunyai risiko 14 kali terpapar diare, dibandingkan dengan bayi yang tidak diberi susu formula. Berdasarkan hasil analisis menunjukkan bahwa responden yang memberikan susu formula kepada bayinya berisiko terkena diare. Pada umur 6 bulan organ pencernaan bayi belum sempurna sehingga mudah terkena diare . hal ini dapat dilihat dari berkurangnya frekuensi defekasi, yang merupakan petunjuk dari semakin matangnya kapasitas "water-conserving" pada usus.

Berdasarkan Tabel 3 diatas dapat dilihat bahwa distribusi responden menunjukkan bahwa bayi yang diberikan tepat penyajian susu formula lebih rendah terjadi diare (33\%) dibandingkan dengan tidak tepat penyajian susu formula terjadi diare (67\%). Sedangkan tepat penyajian susu formula lebih tinggi tidak terjadi diare $(100 \%)$ dibandingkan dengan tidak tepat penyajian susu formula tidak terjadi diare $(0 \%)$. Hasil perhitungan statistic menggunakan diperoleh nilai $\mathrm{p}=0,034$ ( $p$-value $<0,05)$.

Berdasarkan $p$ value yang didapat melalu uji chi square dengan tabel $2 \times 2$ terdapat 1 cell yang memiliki nilai expected di bawah 5, sehingga analisis yang digunakan Fisher Exact Test dengan $p$ value $(0,001)<a(0,05)$ yang berarti $\mathrm{Ha}$ di terima, dimana ada hubungan pemberian susu formula dengan kejadian diare pada bayi usia 0-6 bulan di Desa Tambak Cekur Kecamatan Serba Jadi Kabupaten Serdang Bedagai. Mengacu pada hasil uji tersebut dapat dijelaskan semakin tinggi pemberian susu formula pada bayi 0-6 bulan akan meningkat kejadian diare. Pada penelitian ini perlu pelaksanaan penyuluhan kepada ibu bahwa tidak perlu pemberian susu formula pada bayi 0-6 bulan. 
Hasil penelitian ini sesuai dengan penelitian Apriliya Bina Purwanti (2017) menunjukkan bahwa hubungan antara tindakan pemberian susu formula dengan kejadian diare pada bayi usia 0-6 bulan di RSUD Dr. Soedirman Kebumen. Hasil penelitian ini sejalan dengan penelitian yang dilakukan oleh Nuriza Astari (2013) yang menunjukkan bahwa ada hubungan pemberian susu formula dengan kejadian diare pada bayi 0 6 bulan, dimana $p$ value $=0,001$.

Menurut peneliti Eviyanti (2017) dengan judul Hubungan Pemberian Susu Formula Dengan Kejadian Diare pada bayi usia 0-6 bulan di Wilayah Kerja Puskesmas Jati Raya Sulawesi Tenggara Tahun 2017 Dalam prosesnya, dari 35 responden diperoleh data 22 responden mengalami diare dan 13 responden tidak mengalami diare. Sedangkan responden yang tidak diberikan susu formula sebanyak 12 responden dan responden yang diberikan susu formula sebanyak 23 responden. Berdasarkan tabel menunjukkan, responden yang tidak di beri susu formula dan tidak menderita diare sebanyak 9 orang $(69,2 \%)$. Responden yang di beri susu formula dan tidak menderita diare sebanyak 4 orang $(30,8 \%)$. Sedangkan responden yang tidak diberi susu formula namun menderita diare sebanyak 3 orang $(13,6 \%)$, dan responden yang diberi susu formula dan menderita diare sebanyak 19 orang $(86,4 \%)$.

Faktor yang mendukung tingginya persentase bayi yang tidak mengalami kejadian diare yaitu karena keadaan lingkungan yang baik dinilai dari keadaan penyediaan air bersih, makanan dan kebersihan ibu serta bayi. Sehingga kemungkinan bakteri untuk dapat masuk ke dalam tubuh bayi lebih kecil bila dibandingkan bayi dengan keadaan lingkungan yang kurang. Faktor lain yang mendukung yaitu jika bayi berstatus gizi baik. Dalam keadaan yang demikian tubuh mempunyai cukup kemampuan untuk mempertahankan diri terhadap penyakit infeksi (diare). Hal ini sesuai dengan teori dari Sitorus (2008) yang mengatakan bahwa anak yang tidak kurang gizi akan tahan terhadap serangan penyakit, sedangkan yang kurang gizi akan mudah sakit.

Gizi dan infeksi diare sangat

erat kaitannya. Anak yang mengalami diare dapat menjadi kurang gizi sehingga mudah terkena infeksi. Infeksi dapat pula menyebabkan diare. Hubungan ini membentuk siklus yang berbentuk lingkaran karena saling berhubungan dan masing-masing memberi pengaruh negative. Jika persiapan dan pemberian susu kurang memperhatikan segi antiseptic maka kontaminasi mudah terjadi (Kemenkes RI, 2011).

Susu formula banyak digunakan di negara berkembang, Indonesia termasuk didalamnya. Botol susu yang tidak seril amat berbahaya sehingga menjadi media berkembang biaknya mikroorganisme yang bersifat patogen seperti bakteri, virus dan parasit, yang dapat menyebabkan 
penyakit, salah satunya diare. Hal ini karena pemberian ASI eksklusif pada bayi, akan memberikan kekebalan kepada bayi terhadap berbagai macam penyakit karena ASI adalah cairan yang mengandung zat kekebalan tubuh yang dapat melindungi bayi dari berbagai penyakit infeksi bakteri, virus, jamur dan parasit. Oleh karena itu, dengan adanya zat anti infeksi dari ASI maka anak dapat terlindung dari penyakit diare. ASI steril, berbeda karena tidak perlu disiapkan dengan air atau bahanbahan yang terkontaminasi dalam botol yang kotor.

Bayi yang diberi susu formula dengan cara yang tidak tepat atau tidak sesuai kemasan mempunyai risiko terkena diare sebesar 4,14 dibanding dengan yang diberi susu formula secara tepat. Berdasarkan hasil penelitian ini, masih banyak ibu-ibu yang memberikan susu formula dengan cara yang tidak tepat yaitu tidak sesuai petunjuk kemasan. Selain itu sebagian besar responden tidak mencuci tangan sebelum menyiapkan susu formula hal ini terjadi karena terkadang ibu lupa dan memang tidak terbiasa untuk cuci tangan terlebih dahulu, botol yang dipakai tidak disteril karena responden tidak memiliki alat untuk mensteril botol susu bayi, dan adapun yang mensteril botol susu hanya dengan direbus tanpa mengetahui berapa suhu yang tepat untuk mensteril botol susu tersebut. Penggunaan botol susu yang salah sangat memudahkan pencemaran kuman penyebab diare (Dinkes RI, 2012).
Penelitian-penelitian yang telah dilakukan diketahui bahwa banyak faktor yang mempengaruhi kejadian diare. Penggunaan susu formula semakin meningkat karena dijadikan makanan pendamping ASI. Menurunkan angka kejadian diare pada anak dapat dilakukan dengan cara pemberian susu formula yang benar. Selain itu cara penyimpanan setelah pengenceran, membersihkan botol susu, kebiasaan mencuci tangan mempunyai hubungan dengan kejadian diare. Proses penyeduhan yang terlalu kental merupakan penyebab lain kejadian diare.

\section{KESIMPULAN}

Karateristik responden berdasarkan umur diperoleh frekuensi terbanyak adalah responden dengan umur 17-28 tahun sebanyak 11 orang (55\%). Berdasarkan pendidikan diperoleh hasil frekuensi terbanyak adalah responden dengan pendidikan SMA sebanyak 9 orang (45\%), sedangkan berdasarkan pekerjaan hasil frekuensi terbanyak adalah responden dengan pekerjaan IRT sebanyak 12 orang (60\%).

Distribusi responden berdasarkan cara penyajian susu formula dengan frekuensi terbanyak pada kategori tepat penyajian sebanyak 17 orang (85\%).

Distribusi responden berdasarkan kejadian diare dengan frekuensi terbanyak pada kategori terjadi diare sebanyak 9 orang (45\%).

Adanya hubungan Cara Penyajian Susu Formula Dengan Kejadian Diare di Desa Tambak 
Cekur Kecamatan Serbajadi Kabupaten Serdang Bedagai Tahun 2019.

Disarankan agar Ibu tidak memberikan susu formula pada bayi 0-6 bulan karena dapat meningkatkan angka kejadian diare pada bayi.

\section{DAFTAR PUSTAKA}

Bambang. (2011). Super Baby Directory. Jogjakarta: Flashbook. Cetakan I

Baskoro, A. (2012). ASI Panduan Praktis Ibu Menyusui, Yogyakarta, Banyu Media.

Bina, PA. (2017) . Hubungan Penyajian Susu Formula Terhadap Kejadia Diare di RSUD Dr.Soedirman Kebumen Tahun 2017. Skripsi. Sulawesi

DepKes. (2010). Jakarta: Kementerian Kesehatan RI

Dinkes Provinsi Sumatera Utara, 2012. Profil Kesehatan Provinsi Sumatera utara

Hardi. (2012). Faktor-faktor yang mempengaruhi kejadian diare pada batita di Wilayah Kerja Puskesmas Baranglompo Kecamatan Ujung Tanah tahun 2012. Skripsi. Makassar: UNHAS.

Hidayat, AA. 2008. Pengantar IImu Kesehatan Anak untuk Pendidikan Kebidanan. Jakarta: Salemba.

Kementrian Kesehatan. 2013. Dukung Ibu Bekerja Beri ASI .http://www.depkes.go.id/articl e/print/15091400003/dukungibu-bekerja-beri-asieksklusif.html
Khasanah, Nur.(2011). ASI atau Susu Formula.Jogjakarta: flashbooks.

Kodrat, Laksono, (2010). Dahsyatnya ASI \& Laktasi. Yogyakarta: Media Baca.

Nadesul,

Hendrawan. (2012).Makanan Sehat untuk Bayi. Cetakan VII.Jakarta : Puspa Swara

Nasir (2011). Hasil Penelitian Mengenai Manfaat ASI dan Perbandingannyadengan Susu Formula.

http://dokternasir.web.id//2011 Notoatmodjo, S. (2010). Metodologi Penelitian Kesehatan. Jakarta : Rineka Cipta

Praptiani, Wuri. (2012).Kebidanan Oxford: Dari Bidan untuk Bidan Jakarta: Buku Kedokteran EGC.

RISKESDAS. (2013). Jakarta: Kementerian kesehatan RI.

Roesli, Utami. (2010). Inisiasi Menyusui dini. Jakarta: Pustaka Bunda.

Soenardi. 2011. Makanan untuk Tumbuh Kembang Bayi. Jakarta: Gramedia Pustaka.

Sugiyono.(2010). Statistik untuk Penelitian. Jakarta : Alfa Beta.

Sutomo, B 2010. Menu Sehat Alami untuk Balita dan Batita. PT. Agromedia Pustaka. Jakarta. 